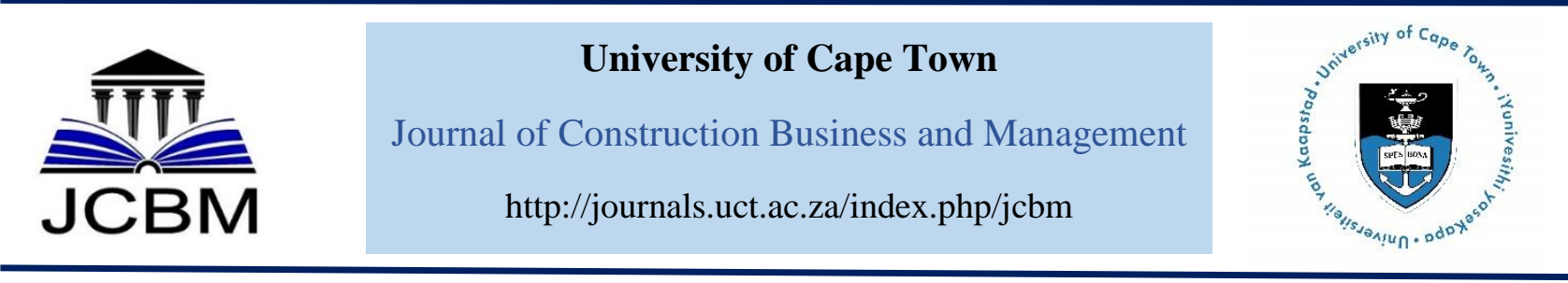

\title{
Evaluation of Risk Factors and their Impact on Road Projects
}

\author{
F. Leo-Olagbaye ${ }^{1}$ and H. Odeyinka ${ }^{2}$ \\ ${ }^{1,2}$ Department of Quantity Surveying, Obafemi Awolowo University, Nigeria.
}

Received 8 January 2018; received in revised form 9 February 2018, 12 April 2018; accepted 19 June 2018 https://doi.org/10.15641/jcbm.2.2.2018.486

\begin{abstract}
Construction projects are generally known to be susceptible to risks. This results in an inability to meet performance targets. This paper assessed the risk factors encountered in the delivery of road projects in Osun State, Nigeria. A questionnaire survey was used to obtain data from all the 146 construction professionals involved in the construction of the 34 road projects executed in the study area. The professionals comprised of 34 Consultant Civil Engineers, 34 Consultants' Civil Engineers, 34 Consultant Quantity Surveyors, 34 Consultants' Quantity Surveyors, one project financier and 9 Project Managers, making a total of 146 respondents. Using two-dimensional scaling, the respondents were asked to provide opinions on risk occurrence and their impacts on road projects. The data collected were analysed using mean ranking analysis and student ttest. A further analysis was carried out using factor analysis to reduce the factors impacting road projects into fewer factor components. The results revealed that the risk factors with high extent of occurrence are in the order of change in scope of work, defective design, error and re-work, change in design, delay in availability of design details and unforeseen adverse conditions. Surprisingly, the top ranking risk factors are not the ones with high impact based on the result of the analysis. Using factor analysis, 9 component factors regarding the extent of risk occurrence were obtained and they accounted for $73.73 \%$ of the variance explained while 4- component factors were obtained regarding the impact of risk occurrence and they accounted for $46.16 \%$ of the variance explained. The study concluded that professionals involved in the delivery of road projects need to be aware of the significant risk factors impacting road projects and put proactive risk management approach in place to deal with them to avoid surprises.
\end{abstract}

Keywords: Performance, Projects, Risk factors, Risk impact, Road.

\section{Introduction}

The National Transport Policy for Nigeria (Federal Government of Nigeria (FGN), 2010) outlined the benefits of efficient infrastructure to include the stimulation of national development, enhancement of quality of life, facilitation of the movement of goods and people, connection of spatially separated facilities, facilitation of community and national integration among others. Awodele, Ogunlana and Motawa (2009) also concluded that road networks are key business drivers. Several attempts have been made by various tiers of government responsible for road construction in Nigeria to successfully deliver road projects, but evidence abounds regarding project abandonment, low quality or delayed delivery, and excessively high construction cost (Udeh and Onwuka, 2015). It has been established that road projects are capital intensive and require proper planning as well as a well-coordinated execution (PMI,2012). The attributes mentioned above make road projects risky and uncertain. The risk and uncertainty result in failure to meet performance targets (Greedy, 2005).

According to Mousavi, Mojtahedi and Makui (2011), road projects have peculiar characteristics; these includes the multiplicity of project participants, substantial financial requirement, complex procurement methods among others. This emphasizes the need to understand the specific risks and deploy appropriate risk management strategies on road projects. As a result of the infrastructure deficit in Nigeria, road projects are being proposed and executed in different locations. Unfortunately, previous studies reported that formal risk management techniques needed to avoid time and cost overruns on projects and enhance profitability were not utilised in the Nigerian

\footnotetext{
${ }^{1}$ Corresponding Author

Email address: feyileo2@gmail.com
} 
construction industry (Windapo et al., 2010 and Dada, 2010).

Studies have been carried out on risk identification and management on construction projects, but limitations abound. For instance, Hazim and Salem (2015) investigated the key factors causing a delay in road projects in Jordan, but the study was based on literature review only. Ehsan et al. (2010) identified the common risks factors and uncertainties within the building industry in Pakistan, but the research was not empirical as it was based on literature review only. Odeyinka et al. (2005) conducted a study on the likelihood of occurrence and impact of risk factors, but the study was limited to building projects only. Similarly, Belel and Mahmood (2012) used a questionnaire survey to assess risk management practices on building projects in Nigeria while Alagwe and Adegoke (2013) analysed risk factors affecting project performance in Southwestern Nigeria, both studies also failed to consider roadworks. Therefore, this study aims to address the identified gap in the literature by identifying and analysing the risk factors impacting road projects in Osun State, Nigeria. The study area was selected because of the preponderance of road projects there at the time of this study. The findings of this study are expected to enhance the success of road projects regarding cost and time performances.

\section{Risk and Road Project Risks}

According to Baloi and Price (2003), risk refers to the possibility of an unfavourable occurrence in the course of executing a project. Devripasadh (2007) submitted that within the construction industry, the risk is perceived as any internally or externally motivated event which negatively affects the objectives of a project. Baloi and Price (2003) submitted that risk concept is influenced by the viewpoint, attitude, and experience of an individual. It is also believed that individuals interpret risk based on areas of practice; for instance, financial managers often perceive risk from the financial standpoint while engineers view it from the technological standpoint (Baloi and Price, 2003). Uncertainties characterise construction projects, this is as a result of issues such as planning needs, design demands, resource sourcing, climatic conditions and economic policies among others (Greedy, 2005).

In the project context, the Association for Project Management (APM) (2012) defines risk as 'an unknown event that, if it occurs, will affect the achievement of one or more project objectives'. Also, the Project Management Institute (PMI) (2016) defines risk as an uncertain occurrence that, if it occurs will have either a positive or negative effect on one or more of the project's objectives'. A peculiar inclusion in the PMI definition is the probability of a risk having either favourable or an unfavourable impact on the objectives of a project. Miller and Lessard (2001) conducted a study on large engineering projects; the study categorised risks according to three sources. The sources are market, completion and instructional; market risks are caused by uncertainties in demand, completion risks can be described as strategic risks occurring at pre and post completion of a project while experimental risks are associated with uncertainties regarding specification (Miller and Lessard, 2001). Smith (1999) agreed that risks in road projects arise from various sources which include technical, environmental, health, political, and market sources. Management of risk is key to a successful project, but assessment of risk is complex and sometimes not understood in practice (Smith, 1999).

Zou et al. (2007) highlighted the common risk factors on road projects to comprise work changes, delay in contract payment, client's financial incapability, and labour issues among others. Similarly, Odeyinka et al. (2007) identified before and after contract risk factors in the construction industry in Nigeria, risk in design, estimating, tendering, and tender evaluation was among the risks identified. In a related study, Cohen and Palmer (2004), identified risk factors in road projects to include project scope change, design errors and omissions, insufficient skilled workers, subcontractors and contractors' experience. Also, Osama and Salman (2003) identified three classes of road risks, comprising of financial risk, time and design-related risks. In contrast, a similar study conducted by Mousavi et al. (2011) classified risk factors involved in road projects under four significant headings namely: engineering, procurement, construction and management.

From the preceding, it is evident that the term 'risk' has several definitions but the fact that it is the likely occurrence of an event is common to all definitions. Also, risk factors are classified under different headings by different authors from various perspectives. It is also interesting to note that risk in construction has been viewed from different perspectives such as the construction industry as a whole, large engineering projects, pre and post-contract stages of building projects, road projects among others. However, the concern of this study is a risk as they relate to road projects. Presented in the next section is the research method adopted in this study.

\section{Research Methods}

This study commenced with a review of related literature to extract the risk factors potentially thought to impact road projects. The survey research design was adopted in carrying out the study as it was considered appropriate in reaching a wider number of respondents. A structured questionnaire survey was administered on construction professionals who participated in road projects in Osun State, Nigeria between 2011 and 2015. Osun state was chosen as the study area because of the preponderance of road projects during the period under consideration. The State comprises of 30 Local Government areas, 1 area office and 3 Senatorial Districts. One road project was selected from each of the 30 local governments, one area office and one from each of the 3 Senatorial Districts giving a total of 34 road projects. All the stakeholders that participated in these road projects were engaged in the questionnaire survey. The stakeholders consist of 34 Consultant Civil Engineers, 34 Consultants' Civil Engineers, 34 Consultants' Quantity Surveyors, 34 Contractors' Quantity Surveyors, one project financier and 9 Project Managers, making a total of 146 respondents who constitute the study population. Due to 
the manageable size, a total enumeration of the study population was engaged in the questionnaire survey. Thus, there was no need for sampling. The questionnaire design was based on 33 risk factors identified from literature and from discussions with professionals involved in road construction. Respondents' opinions were sought using a two-dimensional scaling based on the theory of two-dimensional nature of risk (Williams, 1996). The theory suggests that risk analysis should be based on the pair of risk occurrence and risk impact. A 0 to 5 (i.e. 6-point) Likert-type scale was used to assess respondents' strength of opinions whereby 0 meant no risk occurrence and no impact and 5 meant very high probability of risk occurrence and very high impact. Presented in Table 1 is the background information of the respondents. From the Table, it is evident that the respondents are well experienced with 10.78 mean years of experience. They are highly educated, professionally qualified and they have been previously involved in handling road projects. Thus, the responses provided by them could be relied upon. The outcome of the survey and associated discussions are presented in the next section.

Table 1: Respondents' background information

\begin{tabular}{|c|c|c|c|c|c|}
\hline Background Information & Parameters & Frequency & Per cent & Cum. Freq. & Mean \\
\hline \multirow{5}{*}{ Years of Experience in road construction } & $0-5$ years & 3 & 2.6 & 2.6 & \multirow{5}{*}{10.78} \\
\hline & $6-10$ years & 64 & 55.7 & 58.3 & \\
\hline & $11-15$ years & 32 & 27.8 & 86.1 & \\
\hline & $16-20$ years & 12 & 10.4 & 96.5 & \\
\hline & Over 20 years & 4 & 3.5 & 100 & \\
\hline \multirow{6}{*}{ Professional Designation } & Consultant's CE & 30 & 26.1 & 26.1 & \\
\hline & Contractor's CE & 21 & 18.3 & 44. & \\
\hline & Consultant's QS & 28 & 24.3 & 68.7 & \\
\hline & Contractor's QS & 26 & 22.6 & 91.3 & \\
\hline & Project Financier & 1 & .9 & 92.2 & \\
\hline & Project Manager & 9 & 7.8 & 100 & \\
\hline \multirow{4}{*}{ Educational Qualification } & HND & 17 & 14.8 & 14.8 & \\
\hline & B.Sc/B.Tech/B.Engr & 56 & 48.7 & 63.5 & \\
\hline & M.Sc/M/Tech/MBA & 36 & 31.3 & 94.8 & \\
\hline & $\mathrm{PhD}$. & 6 & 5.2 & 100 & \\
\hline \multirow{5}{*}{ Professional Qualification } & MNSE/FNSE & 35 & 30.4 & 30.4 & \\
\hline & MNIQS/FNIQS & 58 & 50.4 & 80.4 & \\
\hline & $\mathrm{MICE} / \mathrm{FICE}$ & 10 & 8.7 & 89.1 & \\
\hline & MRICS/FRICS & 6 & 5.2 & 94.3 & \\
\hline & MAPM/PMP & 6 & 5.2 & 100 & \\
\hline \multirow{5}{*}{ Road Projects executed in last five years } & $0-5$ & 27 & 23.5 & 23.5 & \multirow{5}{*}{8.80} \\
\hline & $6-10$ & 50 & 43.5 & 67.0 & \\
\hline & $11-15$ & 29 & 25.2 & 92.2 & \\
\hline & $16-20$ & 4 & 3.5 & 95.7 & \\
\hline & Over 21 & 5 & 4.3 & 100 & \\
\hline \multicolumn{2}{|l|}{ Total } & 115 & 100.0 & & \\
\hline
\end{tabular}

A total of 146 questionnaires were administered, and 115 were returned, filled and fit for analysis. Data analysis was done using mean ranking analysis, Student t-test and factor analysis. The mean score was used to rank the risk factors, and it was calculated using the formula in Equation 1.

$M S=\frac{5 \mathrm{n} 5+4 n 4+3 n 3+2 n 2+1 n 1+0 n 0}{n 5+n 4+n 3+n 2+n 1+n 0}$

(Equation 1)

where, MS = Mean Score

$\mathrm{n}_{0}=$ no of respondent who chose "no occurrence" or "no impact"

$\mathrm{n}_{1}=$ no of respondents who chose "very low occurrence"

or "very low impact."

$\mathrm{n}_{2}=$ no of respondent who chose "low occurrence" or

"low impact"

$\mathrm{n}_{3}=$ no of respondent who chose "moderate occurrence"

or "moderate impact"

$\mathrm{n}_{4}=$ no of respondents who chose "high occurrence" or

"high impact." $\mathrm{n}_{5}=$ no of respondents who chose " very high occurrence" or " very high impact."

Student t-test was used to test the hypothesis of no difference between the mean scoring of clients' consultants and contractors' organisations while factor analysis was used to categorise the occurrence of risk factors and their impact on road projects. To establish the adequacy of the factor loading arising from factor analysis the Kaiser-Meyer-Olkin (KMO) and Bartlett's Test of Sphericity were used. The Bartlett's test tests the hypothesis which states that the original correlation matrix is an identity matrix. For the use of factor analysis to be adequate, Kaiser stated that values greater than 0.5 are acceptable, this condition was satisfied in this study.

\section{Presentation of Results}

Presented in this section is the result of data analysis with relevant discussions. 


\subsection{Analysis of extent of occurrence of risk factors in the delivery of road projects}

Table 2 presents the results of data analysis on the extent of occurrence of risk factors in the delivery of road projects. Table 2 shows that the top 5 risks factors regarding occurrence include 'change in project scope', 'defective design, error and rework', 'change in design', 'delay in availability of design details' and 'unforeseen adverse ground condition'. These risk factors have a mean score ranging from 3.64 to 3.73 on a Likert-type scale of $0-5$.

A statistical test using Student t-test was carried out at $5 \%$ level of significance to test the hypothesis that there is no statistical difference in the mean responses of clients' consultants and responses from contractors' organisations on the extent of occurrence of the identified 33 risk factors in the delivery of road projects they were involved with.
Table 2 shows the $\mathrm{t}$ - statistics and the p-values. However, four risk variables namely 'high maintenance cost', 'nonavailability of spare parts for construction plant and equipment', 'shortage of experts in road construction' and 'change in government' were found to have statistically significant different mean values $(\mathrm{P}<0.05)$. Whereas high maintenance cost ranked 6th in the overall mean score, it ranked 13th and 2nd under the client's consultants and contractors' organisations scoring respectively. This is not surprising because contractors are more involved in post construction road maintenance and tend to be more aware of the high cost of maintenance than the consultants who were only involved at the design and construction stages. Hence, they scored this risk factor higher. Similarly, nonavailability of spare parts for construction plant and equipment ranked 23rd and 5th under the client's consultants, and contractors' organisations scoring respectively but ranked 11 th overall.

Table 2: Extent of Occurrence of Identified Risk Factors in the Delivery of Road Projects

\begin{tabular}{|c|c|c|c|c|c|c|c|c|}
\hline Risk Factors & $\begin{array}{c}\text { Overall } \\
\text { Mean } \\
\text { Score } \\
\end{array}$ & $\begin{array}{c}\text { Overall } \\
\text { Rank }\end{array}$ & $\begin{array}{c}\text { Client's } \\
\text { Consultant } \\
\text { Mean } \\
\end{array}$ & Rank & $\begin{array}{c}\text { Contractors' } \\
\text { Organisations } \\
\text { Mean } \\
\end{array}$ & Rank & T-statistic & $P$-values \\
\hline Change in scope of work & 3.73 & 1 & 3.63 & 2 & 3.87 & 1 & 1.604 & 0.208 \\
\hline Defective design, error and rework & 3.70 & 2 & 3.63 & 2 & 3.80 & 5 & 0.881 & 0.350 \\
\hline Change in design & 3.65 & 3 & 3.54 & 7 & 3.80 & 5 & 1.933 & 0.167 \\
\hline $\begin{array}{l}\text { Delay in availability of design } \\
\text { details }\end{array}$ & 3.64 & 4 & 3.51 & 9 & 3.83 & 3 & 2.685 & 0.104 \\
\hline $\begin{array}{l}\text { Unforeseen adverse ground } \\
\text { condition }\end{array}$ & 3.64 & 4 & 3.71 & 1 & 3.54 & 19 & 0.714 & 0.400 \\
\hline High maintenance cost & 3.61 & 6 & 3.45 & 13 & 3.85 & 2 & 5.640 & $0.019^{*}$ \\
\hline Contractors cash flow problem & 3.60 & 7 & 3.62 & 4 & 3.59 & 15 & 0.032 & 0.859 \\
\hline $\begin{array}{l}\text { Poor relationship with the } \\
\text { community }\end{array}$ & 3.59 & 8 & 3.42 & 16 & 3.83 & 3 & 3.918 & 0.050 \\
\hline $\begin{array}{l}\text { Shortage of major road } \\
\text { construction materials }\end{array}$ & 3.56 & 9 & 3.42 & 16 & 3.76 & 9 & 3.301 & 0.072 \\
\hline $\begin{array}{l}\text { Lack of commitment between } \\
\text { parties }\end{array}$ & 3.56 & 9 & 3.55 & 5 & 3.57 & 18 & 0.005 & 0.943 \\
\hline $\begin{array}{l}\text { Non- availability of spare parts for } \\
\text { construction plants and equipment }\end{array}$ & 3.54 & 11 & 3.35 & 23 & 3.80 & 5 & 6.332 & $0.013^{*}$ \\
\hline $\begin{array}{l}\text { Lack of attention to market } \\
\text { conditions }\end{array}$ & 3.54 & 11 & 3.48 & 10 & 3.63 & 14 & 0.729 & 0.395 \\
\hline Subcontractors incompetence & 3.53 & 13 & 3.38 & 20 & 3.74 & 10 & 3.540 & 0.063 \\
\hline $\begin{array}{l}\text { Lack of attention to contract } \\
\text { requirements }\end{array}$ & 3.53 & 13 & 3.54 & 7 & 3.52 & 23 & 0.009 & 0.924 \\
\hline Inclement weather & 3.52 & 15 & 3.48 & 10 & 3.59 & 15 & 0.331 & 0.566 \\
\hline $\begin{array}{l}\text { Shortage of experts in road } \\
\text { construction }\end{array}$ & 3.51 & 16 & 3.32 & 25 & 3.78 & 8 & 6.076 & $0.015^{*}$ \\
\hline Public opposition to projects & 3.51 & 16 & 3.38 & 20 & 3.70 & 12 & 2.270 & 0.135 \\
\hline Shortage of equipment & 3.50 & 18 & 3.35 & 23 & 3.72 & 11 & 3.587 & 0.061 \\
\hline Shortage of skilled labourers & 3.50 & 18 & 3.38 & 20 & 3.65 & 13 & 2.194 & 0.141 \\
\hline $\begin{array}{l}\text { Delay in receiving projects } \\
\text { permits and approval }\end{array}$ & 3.50 & 18 & 3.55 & 5 & 3.43 & 27 & 0.367 & 0.546 \\
\hline Delay in payment by the client & 3.48 & 21 & 3.43 & 14 & 3.54 & 19 & 0.400 & 0.529 \\
\hline Inadequate specification & 3.48 & 21 & 3.48 & 10 & 3.48 & 25 & 0.000 & 0.994 \\
\hline $\begin{array}{l}\text { Failure of major construction } \\
\text { equipment }\end{array}$ & 3.47 & 23 & 3.42 & 16 & 3.54 & 19 & 0.404 & 0.526 \\
\hline Inflation/interest rate fluctuation & 3.46 & 24 & 3.40 & 19 & 3.54 & 19 & 0.517 & 0.474 \\
\hline $\begin{array}{l}\text { Lack of legal, regulatory } \\
\text { framework }\end{array}$ & 3.42 & 25 & 3.31 & 27 & 3.59 & 15 & 2.313 & 0.131 \\
\hline
\end{tabular}




\begin{tabular}{|c|c|c|c|c|c|c|c|c|}
\hline $\begin{array}{l}\text { Lack of communication between } \\
\text { central office and site Office }\end{array}$ & 3.41 & 26 & 3.43 & 14 & 3.37 & 29 & 0.114 & 0.737 \\
\hline Adverse ground condition & 3.38 & 27 & 3.32 & 25 & 3.46 & 26 & 0.536 & 0.466 \\
\hline Foreign exchange rate fluctuation & 3.36 & 28 & 3.25 & 29 & 3.52 & 23 & 1.865 & 0.175 \\
\hline Flood & 3.32 & 29 & 3.25 & 29 & 3.43 & 27 & 0.772 & 0.382 \\
\hline Strong political interference & 3.27 & 30 & 3.31 & 27 & 3.22 & 30 & 0.267 & 0.606 \\
\hline $\begin{array}{l}\text { Government officials demanding } \\
\text { bribe/unjust reward }\end{array}$ & 3.20 & 31 & 3.18 & 31 & 3.22 & 30 & 0.024 & 0.877 \\
\hline $\begin{array}{l}\text { Project documents not issued on } \\
\text { time }\end{array}$ & 3.11 & 32 & 3.15 & 32 & 3.04 & 32 & 0.343 & 0.560 \\
\hline Change in government & 2.95 & 33 & 3.14 & 33 & 2.67 & 33 & 6.345 & $0.013 *$ \\
\hline
\end{tabular}

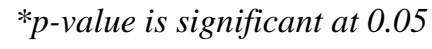

A further analysis was carried out regarding the extent of occurrence of risk factors using factor analysis. The goal was to reduce the 33 risk variables to smaller groups of factors. The principal component analysis "varimax rotation method' was utilised. Table 3 shows the total variance explained and how the variance is distributed among the 33 risk occurrence variables. It should be noted that nine factors have eigenvalues (i.e. a measure of explained variance) greater than 1.0, a common criterion for determining the usefulness of a factor. Together these nine factors accounted for $73.73 \%$ (more than two-thirds) of the variance in the original variables. This suggests that nine component factors were associated with the perception of client's consultants as well as contractor organisations regarding the extent of risk occurrence in the delivery of road projects, but there was room for much-unexplained variation. Tables 3 and 4 show the total variance explained by the factors and the rotated component matrix for the extent of risk occurrence respectively.

Table 3: Total Variance Explained for Extent of Risk Occurrence

\begin{tabular}{|c|c|c|c|c|c|c|c|c|c|}
\hline \multirow{2}{*}{ Component } & \multicolumn{3}{|c|}{ Initial Eigenvalues } & \multicolumn{3}{|c|}{$\begin{array}{c}\text { Extraction Sums of Squared } \\
\text { Loadings }\end{array}$} & \multicolumn{3}{|c|}{$\begin{array}{c}\text { Rotation Sums of Squared } \\
\text { Loadings }\end{array}$} \\
\hline & Total & $\begin{array}{c}\% \text { of } \\
\text { Variance }\end{array}$ & $\underset{\%}{\text { Cumulative }}$ & Total & $\begin{array}{c}\% \text { of } \\
\text { Variance }\end{array}$ & $\underset{\%}{\text { Cumulative }}$ & Total & $\begin{array}{c}\% \text { of } \\
\text { Variance }\end{array}$ & $\underset{\%}{\text { Cumulative }}$ \\
\hline 1 & 10.082 & 30.552 & 30.552 & 10.082 & 30.552 & 30.552 & 3.821 & 11.577 & 11.577 \\
\hline 2 & 3.007 & 9.112 & 39.663 & 3.007 & 9.112 & 39.663 & 3.561 & 10.792 & 22.369 \\
\hline 3 & 2.273 & 6.887 & 46.551 & 2.273 & 6.887 & 46.551 & 2.810 & 8.516 & 30.885 \\
\hline 4 & 1.941 & 5.883 & 52.433 & 1.941 & 5.883 & 52.433 & 2.567 & 7.780 & 38.665 \\
\hline 5 & 1.918 & 5.813 & 58.247 & 1.918 & 5.813 & 58.247 & 2.526 & 7.653 & 46.318 \\
\hline 6 & 1.508 & 4.571 & 62.818 & 1.508 & 4.571 & 62.818 & 2.516 & 7.623 & 53.941 \\
\hline 7 & 1.312 & 3.975 & 66.793 & 1.312 & 3.975 & 66.793 & 2.510 & 7.605 & 61.547 \\
\hline 8 & 1.208 & 3.661 & 70.454 & 1.208 & 3.661 & 70.454 & 2.510 & 7.605 & 69.151 \\
\hline 9 & 1.081 & 3.277 & 73.731 & 1.081 & 3.277 & 73.731 & 1.511 & 4.580 & 73.731 \\
\hline 10 & .881 & 2.671 & 76.401 & & & & & & \\
\hline 11 & .811 & 2.456 & 78.858 & & & & & & \\
\hline 12 & .661 & 2.004 & 80.862 & & & & & & \\
\hline 13 & .654 & 1.983 & 82.845 & & & & & & \\
\hline 14 & .537 & 1.629 & 84.474 & & & & & & \\
\hline 15 & .496 & 1.504 & 85.978 & & & & & & \\
\hline 16 & .477 & 1.445 & 87.422 & & & & & & \\
\hline 17 & .453 & 1.373 & 88.795 & & & & & & \\
\hline 18 & .401 & 1.214 & 90.010 & & & & & & \\
\hline 19 & .384 & 1.165 & 91.174 & & & & & & \\
\hline 20 & .340 & 1.029 & 92.203 & & & & & & \\
\hline 21 & .311 & .942 & 93.145 & & & & & & \\
\hline 22 & .286 & .867 & 94.012 & & & & & & \\
\hline 23 & .270 & .818 & 94.831 & & & & & & \\
\hline 24 & .247 & .748 & 95.579 & & & & & & \\
\hline 25 & .242 & .733 & 96.311 & & & & & & \\
\hline 26 & .219 & .663 & 96.974 & & & & & & \\
\hline 27 & .209 & .632 & 97.607 & & & & & & \\
\hline 28 & .177 & .535 & 98.142 & & & & & & \\
\hline 29 & .161 & .487 & 98.629 & & & & & & \\
\hline 30 & .139 & .420 & 99.049 & & & & & & \\
\hline 31 & .115 & .348 & 99.397 & & & & & & \\
\hline 32 & .111 & .337 & 99.734 & & & & & & \\
\hline
\end{tabular}




\begin{tabular}{llll}
\hline 33 & .088 & .266 & 100.000
\end{tabular}

Extraction Method: Principal Component Analysis

Table 4: Rotated Component Matrix for Extent of Risk Occurrence

\begin{tabular}{|c|c|c|c|c|c|c|c|c|c|}
\hline & \multicolumn{9}{|c|}{ Component } \\
\hline & 1 & 2 & 3 & 4 & 5 & 6 & 7 & 8 & 9 \\
\hline Poor relationship with the community & .826 & & & & & & & & \\
\hline Public opposition to projects & .800 & & & & & & & & \\
\hline Shortage of equipment & .766 & & & & & & & & \\
\hline Shortage of major road construction materials & .664 & & & & & & & & \\
\hline Inflation/interest rate fluctuation & .639 & & & & & & & & \\
\hline Project documents not issued on time & & .841 & & & & & & & \\
\hline Change in government & & .824 & & & & & & & \\
\hline Strong political interference & & .788 & & & & & & & \\
\hline Government officials demanding bribe/unjust reward & & .774 & & & & & & & \\
\hline Foreign exchange rate fluctuation & & .598 & & & & & & & \\
\hline Inadequate specification & & & .789 & & & & & & \\
\hline Delay in receiving projects permits and approval & & & .729 & & & & & & \\
\hline $\begin{array}{l}\text { Non-availability of spare parts for construction plants and } \\
\text { equipment }\end{array}$ & & & .727 & & & & & & \\
\hline Lack of communication between central office and site office & & & .603 & & & & & & .534 \\
\hline Shortage of experts in road construction & & & & .843 & & & & & \\
\hline Shortage of skilled labourers & & & & .790 & & & & & \\
\hline Subcontractors incompetence & & & & .657 & & & & & \\
\hline Lack of commitment between parties & & & & .535 & & & & & \\
\hline Change in scope of work & & & & & .843 & & & & \\
\hline Change in design & & & & & .772 & & & & \\
\hline High maintenance cost & & & & & .727 & & & & \\
\hline Delay in availability of design details & & & & & & & & & \\
\hline Lack of attention to contract requirements & & & & & & .830 & & & \\
\hline Defective design, error and rework & & & & & & 690 & & & \\
\hline Delay in payment by the client & & & & & & & .890 & & \\
\hline Contractors cash flow problem & & & & & & & .805 & & \\
\hline Failure of major construction equipment & & & & & & & .714 & & \\
\hline Adverse ground condition & & & & & & & & .811 & \\
\hline Inclement weather & & & & & & & & .723 & \\
\hline Flood & & & & & & & & .644 & \\
\hline Lack of attention to market conditions & & & & & & & & & .757 \\
\hline Lack of legal regulatory framework & & & & & & & & & \\
\hline
\end{tabular}

Note -Extraction Method: Principal Component Analysis. Rotation Method: Varimax with Kaiser Normalization. Rotation converged in 9 iterations.

The nine principal factors extracted are interpreted as follows (see Table 4 for factor loadings):

Factor 1: Socio-economic risk

Factor 2: Socio-political risk

Factor 3: Project regulation and administration;

Factor 4: Shortage of skilled and committed manpower risk;

Factor 5: Project complexity risk;

Factor 6: Design risk;

Factor 7: Financial risk;

Factor 8: Environmental risk;

Factor 9: Legal and economic risk.

Factor 1: Socio-economic risks

This factor loading incorporates the following five risk variables: poor relationship with community, public opposition to projects, shortage of equipment, shortage of major road construction materials and inflation/interest rate fluctuation. These risk variables have loadings of $0.826,0.800,0.766,0.664$, and 0.639 , respectively.

\section{Factor 2: Socio-political risk}

This factor loading incorporates the following five risk variables: project documents not issued on time, change in government, strong political interference, government officials demanding bribe/unjust reward and foreign exchange rate fluctuation. These five components have loadings of $0.841,0.824,0.788,0.774$, and 0.598 , respectively.

Factor 3: project regulation and administration Loaded on this factor are the following four risk variables: inadequate specification, delay in receiving projects permits and approval, non-availability of spare parts for construction plants and equipment as well as lack of communication between central office and site office. These four components have loadings of $0.789,0.729$, $0.727,0.774$, and 0.603 , respectively. 
Factor 4: a shortage of skilled and committed manpower risk

The four risk variables that loaded onto Factor 4 comprise of a shortage of experts in road construction, shortage of skilled labourers, subcontractors' incompetence and lack of commitment between parties. These four components have loadings of $0.843,0.790,0.657$, and 0.535 respectively.

Factor 5: project complexity risk

Risk variables that loaded unto Factor 5 comprise of change in scope of work, change in design and high maintenance cost. These three components have a loading: $0.843,0.772$ and 0.727 respectively.

\section{Factor 6: design risk}

It is evident from Table 3 that these two risk variables, namely, lack of attention to contract requirements, and defective design, error and rework loaded unto project design risk. These two components have a loading of 0.830 and 0.690 respectively.

\section{Factor 7: financial risks}

Likewise, the three risk variables that loaded onto the seventh factor relates to funding of the project. They comprise of delay in payment by the client, contractors cash flow problem and failure of major construction equipment. This factor was labelled, "financial risks". These three components have factor loadings of 0.890 , 0.805 and 0.714 respectively.

Factor 8: environmental risks

The three risk variables that loaded onto Factor eight are an adverse ground condition, inclement weather and flood. This was labelled, "environmental risks. These three components have factor loadings of $0.811,0.723$ and 0.644 respectively.

Factor 9: Poor legal and economic risks

Lack of communication between central office and site office" had its highest loading from the third factor with a cross-loading over the ninth factor. Lack of attention to market conditions also loaded on this factor. This factor was categorised as "legal and economic risks".

\subsection{Impacts of risk factors in the delivery of road projects}

This section examines the perceptions of client's consultants and contractors' organisations on the impacts of the identified risk factors on the delivery of road projects. The 33 risk factors derived from literature as potentially affecting the delivery of road projects were analysed and presented in Table 5. The result showed that the nine (9) top ranking risk factors with high impacts on the delivery of road projects are 'change in government', 'lack of attention to contract requirements', 'poor relationship with community', 'strong political interference', 'contractors' cash flow problem', 'delay in payment by the clients', 'inflation/interest rate fluctuations', 'unforeseen adverse ground condition' and 'projects documents not issued on time'.

Further analysis with t-test was carried out to test the hypothesis that there was no statistically significant difference in the perceptions of client's consultants and contractors' organisations on the impact of the 33 identified risk factors in the delivery of road projects. The results shown in Table 5 indicates that client's consultants and contractors were mostly unanimous in their scoring of the risk factors impacting the delivery of road projects $(\mathrm{P}<0.05)$. The exceptions are three risk factors with evidence of a statistically significant difference of opinion $(\mathrm{P}<0.05)$. These three risk factors are 'poor relationship with the community', 'defective designs, error and rework' as well as 'adverse ground conditions and they ranked $3 \mathrm{rd}, 13 \mathrm{th}$ and $32 \mathrm{nd}$ respectively in the overall mean score.

Table 5: Impact of identified Risk Factors on Road Projects

\begin{tabular}{|c|c|c|c|c|c|c|c|c|}
\hline Risk Factors & $\begin{array}{c}\text { Overall } \\
\text { Mean } \\
\text { Score } \\
\end{array}$ & $\begin{array}{c}\text { Overall } \\
\text { Rank }\end{array}$ & $\begin{array}{c}\text { Client's } \\
\text { Consultant } \\
\text { Mean } \\
\end{array}$ & Rank & $\begin{array}{c}\text { Contractors' } \\
\text { Organisations } \\
\text { Mean } \\
\end{array}$ & Rank & T-statistic & $P$-values \\
\hline Change in government & 3.61 & 1 & 3.53 & 2 & 3.53 & 2 & 1.423 & .235 \\
\hline $\begin{array}{l}\text { Lack of attention to contract } \\
\text { requirements }\end{array}$ & 3.60 & 2 & 3.53 & 2 & 3.53 & 2 & 1.280 & .260 \\
\hline $\begin{array}{l}\text { Poor relationship with the } \\
\text { community }\end{array}$ & 3.58 & 3 & 3.42 & 12 & 3.42 & 12 & 4.364 & $.039 *$ \\
\hline Strong political interference & 3.55 & 4 & 3.50 & 4 & 3.50 & 4 & .456 & .501 \\
\hline Contractors cash flow problem & 3.53 & 5 & 3.55 & 1 & 3.55 & 1 & .042 & 838 \\
\hline Delay in payment by the clients & 3.52 & 6 & 3.44 & 9 & 3.44 & 9 & 1.416 & .237 \\
\hline Inflation/interest rate fluctuations & 3.50 & 7 & 3.44 & 9 & 3.44 & 9 & .813 & 369 \\
\hline $\begin{array}{l}\text { Unforeseen adverse ground } \\
\text { condition }\end{array}$ & 3.50 & 7 & 3.48 & 5 & 3.48 & 5 & .078 & .780 \\
\hline $\begin{array}{l}\text { Projects documents not issued on } \\
\text { time }\end{array}$ & 3.50 & 7 & 3.44 & 9 & 3.44 & 9 & .697 & .406 \\
\hline Public oppositions to projects & 3.49 & 10 & 3.38 & 17 & 3.38 & 17 & 2.129 & .147 \\
\hline $\begin{array}{l}\text { Failure of major construction } \\
\text { equipment }\end{array}$ & 3.48 & 11 & 3.48 & 5 & 3.48 & 5 & .008 & .929 \\
\hline $\begin{array}{l}\text { Lack of attention to the market } \\
\text { condition }\end{array}$ & 3.44 & 12 & 3.42 & 12 & 3.42 & 12 & .061 & .805 \\
\hline $\begin{array}{l}\text { Defective design, error and } \\
\text { rework }\end{array}$ & 3.43 & 13 & 3.20 & 31 & 3.20 & 31 & 13.177 & $.000^{*}$ \\
\hline
\end{tabular}




\begin{tabular}{|c|c|c|c|c|c|c|c|c|}
\hline Inadequate specifications & 3.43 & 13 & 3.39 & 14 & 3.39 & 14 & .317 & .575 \\
\hline $\begin{array}{l}\text { Lack of legal, regulatory } \\
\text { framework }\end{array}$ & 3.43 & 13 & 3.45 & 7 & 3.45 & 7 & .073 & .788 \\
\hline $\begin{array}{l}\text { Government officials demanding } \\
\text { bribe/unjust reward }\end{array}$ & 3.42 & 16 & 3.36 & 19 & 3.36 & 19 & .679 & .412 \\
\hline Shortage of equipment & 3.41 & 17 & 3.26 & 25 & 3.26 & 25 & 3.795 & .054 \\
\hline $\begin{array}{l}\text { Non-availability of spare parts for } \\
\text { construction plants and equipment }\end{array}$ & 3.39 & 18 & 3.39 & 14 & 3.39 & 14 & .005 & .946 \\
\hline $\begin{array}{l}\text { Lack of communication between } \\
\text { central office and site office }\end{array}$ & 3.37 & 19 & 3.30 & 22 & 3.30 & 22 & .786 & .377 \\
\hline Subcontractors incompetence & 3.36 & 20 & 3.32 & 21 & 3.32 & 21 & .409 & .524 \\
\hline Foreign exchange rate fluctuation & 3.35 & 21 & 3.23 & 28 & 3.23 & 28 & 2.541 & .114 \\
\hline Shortage of skilled labourers & 3.35 & 21 & 3.29 & 24 & 3.29 & 24 & .948 & .332 \\
\hline Change in scope of work & 3.35 & 21 & 3.39 & 14 & 3.39 & 14 & .282 & .596 \\
\hline $\begin{array}{l}\text { Lack of commitment between } \\
\text { parties }\end{array}$ & 3.35 & 21 & 3.24 & 27 & 3.24 & 27 & 1.755 & .188 \\
\hline $\begin{array}{l}\text { Delay in receiving projects permit } \\
\text { and approval }\end{array}$ & 3.33 & 25 & 3.33 & 25 & 3.21 & 29 & 2.235 & .138 \\
\hline Inclement weather & 3.33 & 25 & 3.33 & 25 & 3.45 & 7 & 2.955 & .088 \\
\hline $\begin{array}{l}\text { Delay in availability of design } \\
\text { details }\end{array}$ & 3.30 & 27 & 3.30 & 27 & 3.18 & 33 & 2.853 & .094 \\
\hline Change in design & 3.30 & 27 & 3.30 & 27 & 3.33 & 20 & .217 & .643 \\
\hline $\begin{array}{l}\text { Shortage of major road } \\
\text { construction materials }\end{array}$ & 3.29 & 29 & 3.29 & 29 & 3.21 & 29 & 1.058 & .306 \\
\hline $\begin{array}{l}\text { Shortage of experts in road } \\
\text { construction }\end{array}$ & 3.29 & 29 & 3.29 & 29 & 3.26 & 25 & .229 & .633 \\
\hline High maintenance cost & 3.29 & 29 & 3.29 & 29 & 3.30 & 22 & .024 & .878 \\
\hline Adverse ground condition & 3.22 & 32 & 3.22 & 32 & 3.38 & 17 & 4.995 & $.027 *$ \\
\hline Flood & 3.21 & 33 & 3.21 & 33 & 3.20 & 31 & .038 & .845 \\
\hline
\end{tabular}

p-value is significant at 0.05

Using factor analysis, a further analysis was done to reduce the 33 risk variables to smaller groups of factors impacting the delivery of road projects. The varimax rotation method in the Principal Component analysis was employed. The KMO obtained from the analysis was 0.734, and it falls into the range of 'good'. This confirms the appropriateness of the use of factor analysis for the data set. Similarly, Bartlett's test is highly significant ( $\mathrm{p}=$ 0.000 ) and further confirms that factor analysis is appropriate. The four impact factors generated accounted for $46.16 \%$ of the variance explained (see Table 6). Tables 6 and Table 7 show the total variance explained by the factors and the rotated component matrix for the impacts of risk respectively

Table 6: Total Variance Explained for Impact of Risk Factors

\begin{tabular}{|c|c|c|c|c|c|c|c|c|c|}
\hline \multirow{2}{*}{ Component } & \multicolumn{3}{|c|}{ Initial Eigenvalues } & \multicolumn{3}{|c|}{$\begin{array}{c}\text { Extraction Sums of Squared } \\
\text { Loadings }\end{array}$} & \multicolumn{3}{|c|}{$\begin{array}{l}\text { Rotation Sums of Squared } \\
\text { Loadings }\end{array}$} \\
\hline & Total & $\begin{array}{c}\% \text { of } \\
\text { Variance }\end{array}$ & $\begin{array}{c}\text { Cumulative } \\
\%\end{array}$ & Total & $\begin{array}{c}\% \text { of } \\
\text { Variance }\end{array}$ & $\begin{array}{c}\text { Cumulative } \\
\%\end{array}$ & Total & $\begin{array}{c}\% \text { of } \\
\text { Variance }\end{array}$ & $\begin{array}{c}\text { Cumulative } \\
\%\end{array}$ \\
\hline 1 & 6.926 & 20.988 & 20.988 & 6.926 & 20.988 & 20.988 & 4.628 & 14.023 & 14.023 \\
\hline 2 & 3.670 & 11.122 & 32.110 & 3.670 & 11.122 & 32.110 & 3.952 & 11.975 & 25.998 \\
\hline 3 & 2.384 & 7.225 & 39.335 & 2.384 & 7.225 & 39.335 & 3.795 & 11.499 & 37.498 \\
\hline 4 & 2.253 & 6.828 & 46.163 & 2.253 & 6.828 & 46.163 & 2.860 & 8.666 & 46.163 \\
\hline 5 & 1.907 & 5.780 & 51.943 & & & & & & \\
\hline 6 & 1.649 & 4.998 & 56.941 & & & & & & \\
\hline 7 & 1.560 & 4.728 & 61.670 & & & & & & \\
\hline 8 & 1.388 & 4.207 & 65.877 & & & & & & \\
\hline 9 & 1.308 & 3.963 & 69.839 & & & & & & \\
\hline 10 & 1.079 & 3.270 & 73.109 & & & & & & \\
\hline 11 & .958 & 2.904 & 76.013 & & & & & & \\
\hline 12 & .778 & 2.357 & 78.371 & & & & & & \\
\hline 13 & .685 & 2.077 & 80.448 & & & & & & \\
\hline 14 & .664 & 2.011 & 82.458 & & & & & & \\
\hline 15 & .560 & 1.696 & 84.154 & & & & & & \\
\hline 16 & .516 & 1.563 & 85.717 & & & & & & \\
\hline 17 & .482 & 1.462 & 87.179 & & & & & & \\
\hline
\end{tabular}




\begin{tabular}{llll}
\hline 18 & .458 & 1.387 & 88.566 \\
19 & .424 & 1.284 & 89.851 \\
20 & .396 & 1.201 & 91.051 \\
21 & .344 & 1.041 & 92.093 \\
22 & .325 & .985 & 93.078 \\
23 & .322 & .975 & 94.052 \\
24 & .287 & .870 & 94.922 \\
25 & .251 & .762 & 95.684 \\
26 & .237 & .718 & 96.402 \\
27 & .230 & .696 & 97.098 \\
28 & .211 & .638 & 97.736 \\
29 & .178 & .540 & 98.275 \\
30 & .161 & .488 & 98.763 \\
31 & .149 & .450 & 99.214 \\
32 & .135 & .408 & 99.621 \\
33 & .125 & .379 & 100.000 \\
\hline
\end{tabular}

Table 7: Rotated Component Matrix for Impact of Risk Factors

\begin{tabular}{|c|c|c|c|c|}
\hline & \multicolumn{4}{|c|}{ Component } \\
\hline & 1 & 2 & 3 & 4 \\
\hline Subcontractors incompetence & .713 & & & \\
\hline Shortage of experts in road construction & .689 & & & \\
\hline Delay in availability of design details & .673 & & & \\
\hline Shortage of skilled labourers & .661 & & & \\
\hline High maintenance cost & 619 & & & \\
\hline Lack of commitment between parties & .585 & & & \\
\hline Defective design, error and rework & .564 & & & \\
\hline Lack of attention to contract requirements & .544 & & & \\
\hline Change in scope of work & .542 & & & \\
\hline Change in design & .524 & & & \\
\hline \multicolumn{5}{|c|}{ Non-availability of spare parts for construction plants and equipment } \\
\hline Shortage of equipment & & .701 & & \\
\hline Poor relationship with community & & 670 & & \\
\hline Public oppositions to projects & & 643 & & \\
\hline Shortage of major road construction materials & & 643 & & \\
\hline Adverse ground condition & & 638 & & \\
\hline Inclement weather & & 622 & & \\
\hline Flood & & .548 & & \\
\hline \multicolumn{5}{|l|}{ Change in government } \\
\hline Failure of major construction equipment & & & .726 & \\
\hline Delay in payment by the clients & & & 690 & \\
\hline Contractors cash flow problem & & & 674 & \\
\hline Lack of legal regulatory framework & & & .574 & \\
\hline Delay in receiving projects permit and approval & & & .559 & \\
\hline Unforeseen adverse ground condition & & & .545 & \\
\hline \multicolumn{5}{|l|}{ Inadequate specifications } \\
\hline \multicolumn{5}{|l|}{ Lack of communication between central office and site office } \\
\hline \multicolumn{5}{|c|}{ Lack of attention to market condition } \\
\hline Government officials demanding bribe/unjust reward & & & & .788 \\
\hline Foreign exchange rate fluctuation & & & & .727 \\
\hline Strong political interference & & & & 679 \\
\hline Projects documents not issued on time & & & & .528 \\
\hline Inflation/interest rate fluctuations & & & & .510 \\
\hline
\end{tabular}

Note - Extraction Method: Principal Component Analysis. Rotation Method: Varimax with Kaiser Normalization. Rotation converged in 4 iterations.

The four principal factors extracted are interpreted as follows (see Table 7 for factor loadings):

Factor 1: Project complexity risk;

Factor 2: Logistic, social and environmental risk;

Factor 3: Political and financial risks;
Factor 4: Socio-economic risks.

Factor 1: Project Complexity Risk

In all, nine risk variables loaded into factor 1: Project complexity risk. The risk variables are subcontractors' incompetence, shortage of experts in road construction, 
delay in availability of design details, shortage of skilled labourers, high maintenance cost, lack of commitment between parties, defective design, error and rework, lack of attention to contract requirements, change in scope of work and change in design. These nine components have a loading: $0.713,0.689,0.673,0.661,0.619 .0 .585,0.564$, $0.544,0.542$ and 0.524 respectively.

Factor 2: Logistic, social and environmental risk In all, seven risk variables loaded into factor 2: logistic, social and environmental risk. These risk variables are a shortage of equipment, poor relationship with the community, public oppositions to projects, shortage of major road construction materials, adverse ground condition, inclement weather and flood. These seven components have factor loadings of $0.701,0.670,0.643$, $0.619,0.638,0.622$, and 0.548 respectively.

\section{Factor 3: Political and financial risks}

A total of 6 risk variables loaded into factor 3: political and financial risk. These comprise of failure of major construction equipment, delay in payment by the clients, contractor's cash flow problem, lack of legal, regulatory framework, delay in receiving projects permit and approval and unforeseen adverse ground condition. These six components have factor loadings of $0.726,0.690$, $0.674,0.574,0.559$, and 0.545 respectively.

Factor 4: Risks relating to socio-economic issues A total of 5 risk variables loaded into factor 4: risks relating to socio-economic issues. The risk variables are government officials demanding bribe/unjust reward, foreign exchange rate fluctuation, strong political interference, projects documents not issued on time and, inflation/interest rate fluctuations. These five components have factor loadings of $0.788,0.727,0.679,0.528$ and 0.510 respectively.

\section{Discussion of findings}

The top-ranking risk factors, regarding the extent of occurrence of risk factors (Table 2) relate to project scope, design issues and ground condition. These are usually areas of considerable uncertainty and pose great concerns to construction professionals in the delivery of road projects. Contractors' organisation scored these risk factors higher than the client's consultants because being more directly involved in project execution; they are constantly confronted with the issues. Generally, the result (Table 2) showed that client's consultants and contractors' organisations agreed on their scoring of the degree of risk occurrence in the delivery of road projects. There is a statistically significant difference in the ratings of the two groups of respondents on only four out of thirty-three factors.

On the impact of the risk factors, this study revealed that political as well as economic issues impact much more on the delivery of road projects in Nigeria while issues relating to scope changes and design issues tend to occur more. Surprisingly, the order of impact differs from the order of extent of risk occurrence. For instance, the impact of 'contractors cash flow problem', 'delay in payment by the clients', and 'inflation/interest rate fluctuations' are high (Table 5) but their probability of occurrence was negligible. These risk factors could be the result of bureaucracy involved in the processing of certificates, invoices and valuations. Buertey et al. (2012a) and Oyewobi et al. (2011) conducted studies in Ghana and Nigeria respectively on risks impacts on construction projects and confirms that this category of risk factors has the greatest impact on construction. The differing order of impact and occurrence underscores the theory of two-dimensional nature of the risk (Williams, 1996). This circumstance was also described in a study on risk factors impacting construction cash flow forecast by Odeyinka et al. (2008). Contractors' organisations and client's consultants ranked high the impact of 'contractors cashflow problem' - a financial risk (Table 5), this indicates that irrespective of the value of contracts, the impact of financial risks on road project is high. Buertey et al. (2013) submitted that the effect of financial risks on projects cannot be overemphasized, as they have the high propensity to affect the cash flow of projects which can result in a delay.

Generally, it can be argued that client's consultant and contractors' organisations were largely unanimous on their ratings of risk impacts and their rating of the extent of occurrence of risks on road projects. However, few factors were also rated far apart by the two groups of respondents. For instance, non-availability of spare parts for construction plant and equipment ranked 23rd and 5th under the client's consultants, and contractors' organisations scoring respectively but ranked 11 th overall (Table 2). It can be said that contractors' organisation scored these risk factors higher than the consultants because they are more aware of the non-availability of spare parts for construction plant and equipment. The consolidation of the 33 risk factors using factor analysis revealed the occurrence of social, economic, legal, political and environmental risks among others, while project complexity, logistic, political and socio-economic risks best describes the substantial risks impacting road projects. It is essential that proactive arrangements be made to manage the risks when they are occurring.

\section{Conclusions}

Several attempts have been made by various tiers of government responsible for road construction in Nigeria, but evidence abounds regarding project abandonment, low quality or delayed delivery, and excessively high construction cost. Based on the findings from this study, three main conclusions are offered. First, 33 risk variables were identified as occurring in the delivery of road projects in Osun State, Nigeria and they variously impact the delivery of road projects. The risk factors could be reduced to nine component factors, namely; socioeconomic risk, socio-political risk, project regulation and administration risk, shortage of skilled and committed manpower risk, project complexity risk, design risk, financial risk, environmental risk, and legal and economic risk. Out of all these factors, the risk factors with the highest level of occurrence related to project scope changes, design issues and the problem with site conditions. This implies that the construction contractors and designers need to be aware of these risk factors as a whole and the most important ones to focus on so they can be proactive in managing them. 
Second, the 33 identified risk factors impacting the delivery of roadworks in Osun State, Nigeria could be reduced to four principal factors, namely: project complexity risk, logistic, social and environmental risk, political and financial risks, and socio-economic risks. Out of all these factors, the risk variables with the highest level of impact relate to political and economic issues. This implies that the construction contractors and Consultants need to have an awareness of the risk factors impacting road projects and pay particular attention to those with high impacts for effective management.

Third, the fact that the set of risk factors with a high level of occurrence is different from the set of risk factors with a high level of impact underscores the purpose of exploring the two-dimensional nature of risk in risk analysis and management.

\subsection{Recommendation References}

Akintoye, A. and MacLeod, M. (1997) Risk analysis and management in construction. International Journal of Project Management, 15(1), 31-38.

Awodele, O. A., Ogunlana, S. O. and Motawa, I. (2009) Understanding and Managing Risks Necessary Condition for Success and Sustainability of Privately Financed Market Projects in Nigeria.Proceedings of the Fourth 69 International Conference for Post-Graduate Researchers of the Built and Natural Environment at Glasgow Caledonian University, Scotland.

Baloi, D. and Price, A. D. (2003) Modelling Global Risk Factors Affecting Construction Cost Performance. International Journal of Project Management, 21, 261269.

Buertey, J.I.T., Abeere-Inga, E. and Kumi, T.A. (2012a) Successful delivery of infrastructural projects: Epistemic overview of cost risk and uncertainties.Journal of Civil Engineering and Architecture, 6(9), 1218-1229.

Buertey, J.I.T., Abeere-Inga, E. and Kumi, T.A. (2012b) Estimating cost contingency for construction projects: The challenge of systemic and project specific risk. In: Laryea, S., Agyepong, S.A., Leiringer, R. and Hughes, W. (Eds) Procs 4th West Africa Built Environment Research (WABER) Conference, 24-26 July 2012, Abuja, Nigeria, 413-426.

Chapman, R. J. (2001) The Controlling Influences on Effective Risk Identification and assessment for Construction Design Management, International Journal of ProjectManagement, 19 (3), 147 - 160.

Cohen, M.W. and Palmer, G.R. (2004) Project Risk Identification and Management, AACEInternational Transactions

Comrey A. L. and Lee H. B. (1992) A First Course in Factor Analysis Hillsdale New Jersey; Erlbaum 2ndEds

Dada, J.O (2010) On strategies for mitigating risk in construction projects, The 40th Annual General Meeting/Conference of the Nigeria Institute of Building (NIOB), Asaba, Delta State, July 7-11.

Ehsan, N., Mirza, E., Alam, M. and Ishague, A. (2012) Risk Management in Pakistani Construction Projects. 3rd IEEE Conference on Computer Science and Information Technology, pp. 16-21.
Based on the above conclusions, the following recommendation is proposed; The construction Contractors and Clients Consultants should pay close attention to the identified top-ranking risk factors with high extent of occurrence and impact. A devise pro-active approach is needed to manage them.

\subsection{Suggestions for Further Research}

The study was limited to Road projects. The study area was also restricted to Osun State of South Western Nigeria. The study can be further extended to other parts of the country as well as to building projects. Also, there is a need for the use of many more road projects in developing risk impact models and exploring the use of other modeling techniques like artificial intelligence to achieve more reliable results.

Federal Government of Nigeria, (2010) Draft National Transport Policy of Nigeria, Abuja, Government Press.

Fong, S W (1987) Risk management. The Cost Engineer, 25, 12-16.

Greedy G. (2005) Risk Factors Leading to Cost Overrun in Highway Projects, Queensland University of Technology, Australia.

Hastak, M. and Shaked, A. (2000) ICRAM-1: model for international construction risk assessment.JournalofManagement in Engineering, 16(1), 59-67.

Hinton, P.R., Brownlow, C., McMurray, I., and Cozens, B. (2005) SPSS explained, Routledge Taylor \& Francis Group, New York USA.

Hulett, D., (2004) Using quantitative risk analysis to support strategic decisions. Consult gee executivebriefingsinbusiness risk management

Heemstra, F.J. and Kusters, R.J. (1996) Dealing with risk: a practical approach. Journal of Information Technology, 11, 333-346.

Hulett, D., (2006) Decision Tree Analysis for the Risk Averse Organization.PMI EMEA Congress in Madrid, Spain, May 9, 2006

Miller, R. and Lessard, D. (2001) Understanding and Managing Risks in Large Engineering Projects, International Journal of Project Management, 19, 437 443

Mousavi, S.M., Mojtahedi, S. M. H., and Makui, A. (2011) Project risk identification and assessment simultaneously using multi-attribute group decision making technique. Safety Science, 48, 499-507.

Odeyinka, H.A., and John G. Lowe. (2000) An assessment of risk factors involved in modelling cash flow forecasting. Procs 16th Annual ARCOM Conference, Glasgow, Caledonian University. Association of Researchers in Construction Management, Vol. 2, 557-65.

Odeyinka, H. A, Lowa.J.G.and A. Kaka (2008) An evaluation of risk factors impacting construction cash flow forecast, Journal of Financial Management of Property and Construction, 13(1), 5-17.

Odeyinka, H. A., Oladapo, A. A. and Dada, J. O. (2005) An Assessment of Risk in Construction in the Nigerian Construction Industry. International Symposium on Globalisation and Construction, Construction in Developing Economies, 107, pp. 359-368 
Osama, A. J. and Salman, A. (2003). Risk Assessment in Construction. Journal of Construction Engineering and Management, 129(5), 492-500.

Oyewobi, L.O., Ibrahim, A.D., and Ganiyu, B.O. (2012) Evaluating the impact of risk on contractor's tender figure in public buildings Projects in Northern Nigeria. Journal of Engineering, Project, and Production Management, 2(1), 2-13.

Project Management Institute, (PMI) (2016) A guide to project management body of knowledge (PMBOK®Guide). Newton Square, PA: Project Management Institute.

Smith, N. (1999). Managing Risk in Construction Projects, Smith, N.J., Merna, T. and Jobling, P.(Eds). Oxford: Blackwell Science Ltd.
Udeh, S. N. and Onwuka I. O. (2015) Transforming Road Infrastructure in Nigeria - Revisiting the PublicPrivate Partnership Option. International Journal of Development Research. Vol. 5 (7), 5111-5120.

Williams, T.M. (1996), “The two-dimensionality of project risk', Int. J. Project Management, 14 (3),

185-6.

Windapo, A.O., Omeife, C. and Wahab, L.A (2010) Stakeholders perception of key risks in oil and gas construction projects, Paper presented at the 40th Annual Conference and General Meeting of the Nigerian Institute of Building (NIOB), July 7-11, Asaba, Delta State

Zou, P., Zhang, G. \& Wang, J-Y., (2007) Understanding the key risks in construction projects in China. International Journal of Project Management. 25, $601-614$ 